\title{
The Spread of Nationalism using Social Media
}

\author{
Dewi Kartika Sari dan Ester Krisnawati \\ Program Studi Ilmu Komunikasi Universitas Kristen Satya Wacana \\ Jalan Diponegoro No.52-60 Salatiga 50711 \\ email : dewikaes@gmail.com
}

\begin{abstract}
Abstrak
Artikel ini merupakan hasil penelitian yang didanai oleh Kementerian Riset, Teknologi dan Pendidikan Tinggi Republik Indonesia. Penelitian ini dilatarbelakangi karena banyaknya pengguna Facebook di Indonesia, disertai munculnya grup-grup etnis di Facebook. Penelitian ini menggunakan pendekatan kualitatif. Tahap awal penelitian ini adalah identifikasi status anggota kelompok etnis yang berkaitan dengan penyebaran nasionalisme. Data posting status tersebut kemudian akan dianalisis. Untuk memperdalam analisis, peneliti melakukan wawancara kepada pengelola akun grup kelompok etnis di Facebook. Peneliti juga mewawancara ketua kelompok dan anggota etnis di grup Facebook tersebut. Teori yang digunakan dalam penelitian ini adalah Imagined Community dari pemikiran Benedict Anderson. Hasil penelitian menunjukkan bahwa kelima kelompok etnis menggunakan grup Facebook untuk menjalin komunikasi dan menyebarkan nilai-nilai kebangsaan Indonesia.
\end{abstract}

Kata Kunci: nasionalisme, etnisitas, Facebook, akun grup

\begin{abstract}
This article is the result of research funded by the Ministry of Research, Technology and Higher Education of Republic Indonesia. This research was conducted because of existing a lot of facebookers in Indonesia and raising many groups affiliated to ethnicities which used facebook. This research was qualitative approach. First stage in this research is to identify members status within groups in related to spreading of nationalism. Data of postings in facebook were analyzed. To sharpen analysis, researcher also interviewed chair person of group and member of group. The theory that was used in this research was imagined community from Benedict Anderson's thought. The result showed that the fifth group used facebook group to inter-connecting for communication and spreading of Indonesia nationalism values
\end{abstract}

Keywords: Nationalism, ethnicitites, facebook, group account 


\section{Introduction}

This article is the result of research funded by the Ministry of Research, Technology and Higher Education of Republic Indonesia 2016 in Penelitian Dosen Muda scheme. The research is to discuss about nationalism. The discussion about nationalism is certainly familiar. The study of nationalism has been written and conducted many times. The paper written by Bambang Purwanto entitled Memahami Kembali Nasionalisme Indonesia which was published in Jurnal Ilmu Sosial dan Ilmu Politik in 2001 is one of the examples of scientific study discussing about nationalism in Indonesia. Furthermore, the paper written by Winner Silaban in 2012 entitled Pemikiran Soekarno tentang Nasionalisme which was published in Jurnal Dinamika Politik also talks about nationalism from the perspective of Indonesian national figures. These two papers are examples of researchers that discuss about nationalism in the abstract level.

The discussion about nationalism in the empirical level has also been conducted many times. For example, several Indonesian movies have promoted nationalism. In 2009, a movie entitled Garuda di Dadaku talks about an Indonesian boy who dreams to become a professional soccer player and play for his country in international competition. A movie entitled King which was also released in 2009 tells about a biography of an Indonesian badminton player, Liem Swie King who was victorious in 1980s. Movies entitled Minggu Pagi di Victoria Park and Tanah Air Beta are two movies released in 2010 that also tell about nationalism. In 2015, there was a plan to release a movie about a national figure, HOS Tjokroaminoto.

There is another different empirical fact in online media. Detik.com in March 31, 2015 stated that to stop the advance of radicalism, especially ISIS in Indonesia, Ministry of Communication and Information of Republic of Indonesia (Kominfo) blocked 22 sites that were considered to be radical (http://news.detik.com/re ad/2015/03/31/152723/2874887/10/). Moreover, Indonesian National Counter-Terrorism Agency
(BNPT) defined radicalism as: (1) wanting to make rapid changes by using violence in the name of religion; (2) practicing takfiri or accusing members of other religions as apostasy; (3) supporting, spreading and encouraging other people to join ISIS/IS; (4) interpreting jihad limitedly (http://www.cnnindonesia.com/ teknologi/20150401093434-185-43429/kriteriasitus-islam-radikal-versi-bnpt/).

Scientific study and movie about nationalism in the empirical level did not appear suddenly. Discussion about nationalism in the abstract and empirical levels starts from the social fact faced by Indonesia. Geographically, Indonesia has an area of 1,904,569 $\mathrm{km}^{2}$ which consists of 17,508 islands (http://www.indonesia. go.id/in/sekilas-indonesia/geografi-indonesia). Indonesia has more than 1,071 ethnicity groups. With the wide area and variety of ethnicity, nationalism has become an interesting topic to discuss. The discussion about nationalism nowadays has faced a new challenge. As explained in the previous section, nationalism discourse is not only limited to scientific study and discussion in mass media, or to be exact in movie. It is also challenged by the development of communication and information technology. This new challenge is a form of convergence from mass media. For example, movies in 1990s which could only be watched in the cinema now can be watched in our home using VCD player. We can even watch movies in Youtube if we have a computer, laptop or cell phone that is connected to an internet. This convergence of media then becomes the new challenge for nationalism.

Internet, which specifically is a technology that is able to converge the functions of mass media, has social media which currently are favored by Indonesian people. One of the social media that is used by many Indonesian people until now is Facebook. It is supported by the report from eMarketer which stated that Indonesia ranks third in the world after United States and India in the use of Facebook (http:// www.emarketer.com/Article/Facebook-Closeson-1-Billion-Mobile-Users-Worldwide/1011881 


\section{$/ 1$ ecid=PR1002).}

Some ethnicity groups in Indonesia also use Facebook to build friendship and relationship between the members of their ethnic. They can share their perspectives, upload the photos of their group activities, etc. which can support the existence of the group itself. Therefore, the use of communication and information technology also becomes a challenge for nationalism in Indonesia.

This research focuses on the spread of nationalism in social media, especially Facebook by the ethnicity groups that have Facebook group accounts. This study is important to be conducted because so far, there is no study on nationalism issue in social media. Furthermore, this study is important because the use of internet in Indonesia, which has the potential to disintegrate society, has increased significantly. Therefore, this research is conducted to find out how is the spread of nationalism in social media, especially Facebook.

According to Soekarno, as the Father of the Nation (in Silaban, 2012), nationalism is the basis in building the independence of a nation. Independence of a nation is needed as it is the major principle in realizing the nation's dream to be an independent, sovereign, just and prosperous nation without any kinds of colonialism.

Anderson (in Adisusilo, 2010), defined a nation as "an imagined political community and imagined as both inherently limited and sovereign". According to Anderson, the use of the term "imagined" is important because the majority of the members of this nation have never met each other. However, at the same time, there is an imagination in their mind that they are parts of a particular community. Therefore, the meaning of nationalism here is further understood as something that is alive and dynamic. This perspective presupposes that nationalism is something that is alive, dynamic and developing which look for new forms along with the development and future demands.

This research uses Benedict Anderson's concept of nationalism. An interesting thing about Anderson's concept is that nationalism is something that is alive, dynamic and developing which look for new forms along with the development and future demands. Based on this concept, the era of communication and information technology will give birth to new interpretation of nationalism and forms of the spread of nationalism according to the development of communication and information technology nowadays.

According to McQuail, new media is a place where communication channel is decentralized; message distribution via satellite; ....; the involvement of audience in the increasing communication process; the increasing frequency of interactive communication (two ways) and the increasing flexibility to determine the form and content using digitalization of message (Nicholas 2006:56).

Ron Rice emphasized on the capability of two-way use or operation of a computer and telecommunication in defining new media. $\mathrm{He}$ defined it as a communication technology which specifically involves the capability of a computer (microprocessor and mainframe) to allow or facilitate interactivity between users or between user and information (Rice, 1984:35)

New media is a terminology to explain the convergence in computerized digital communication technology which is connected to a network. An example of media which can represent new media is internet. According to McQuail in his book entitled Teori Komunikasi Massa (2011:43), the main characteristics of new media are the existence of interconnectedness, access to individual as a message receiver or sender, interactivity, various benefits as an open character and its omnipresence.

New media, in this case is internet, influences how an individual communicates with other individuals. Internet exists to fulfill human's necessities in communicating and getting information. Internet functions as a global network to communicate from one place to another place in the world. It also plays a role as an information provider that has no limitation. 
New media, in this case is internet, eventually functions as social media. Through social media, the pattern of public communication is no longer limited to space and time. As stated by Mcluhan in his theory, medium is an extension of human faculties. Internet has various types of services which are realized in various forms, starting from news portal to social media website. Social media have become new interaction media that create spaces for society to share, tell stories and give their opinions. One of the social media which is still used by many people is Facebook.

Facebook is a social network service launched on February 4, 2004, operated and owned by Facebook, Inc. Facebook was founded by Mark Zuckerberg, a Harvard college student and an alumnus of Ardsley High School who was born on May 14, 1984. Users can create personal profile, add other users as friends and exchange messages including automatic notifications when they update their profiles. Moreover, users can join groups with particular purposes, sorted by the working place, school, university or other characteristics.

Facebook can also be used as a way to share something, such as photo, video or internet link. With the "like" and "share" features, we are able to not only share our status, photo, video or personal link, but also our Facebook friends'. Using Facebook group and fan page, we can also reach many people who have the same specific interests, such as job, culture, hobby or even interest in particular figures. Facebook also has many applications and games which can be accessed online by its users, such as "Zinga Poker" and others to attract more users, especially teenagers and children. Furthermore, it can also be used as a means of advertising and information sharing, such as news, issues and others.

As a social network, Facebook has become a new medium used by human to exchange information using internet service. With the advancement of technology, people can access Facebook anytime and anywhere by using their smart phones. Using Facebook, people can be reunited with their old friends, build relationship that once was cut off and communicate swiftly even though there is a considerable distance between the users. It can also function as an online promotion medium to facilitate someone who wants to promote their products. Moreover, Facebook can also be used as a fast discussion forum. Comments that are written by someone freely will be responded by other people so it can be used as a good discussion forum to exchange opinions. Moreover, we can also know someone's feelings through Facebook. Those benefits are the reasons why Facebook has many users from teenagers to older people.

\section{Method of Research}

This research was conducted in Satya Wacana Christian University for 6 months. The observed unit of this research is the spread of nationalism in social media in five ethnicity groups that have Facebook groups, namely: (1) HIMPPAR (Himpunan Mahasiswa dan Pelajar Papua Barat); (2) Batak UKSW \& Grup Pecinta Budaya Batak; (3) KBBS (Keluarga Besar Bali Salatiga); (4) HIPMA (Himpunan Mahasiswa Ambon); and (5) PAMPAKAT (Persatuan Mahasiswa Asal Kalimantan Tengah).

This research uses qualitative descriptive approach. The data collection techniques are observation and content analysis of the group or individual statuses in the Facebook group. The data were also collected from in-depth interviews or focus group discussions (FGD) with the group administrators, leaders and members. Data triangulation was taken from the interviews with communication expert and anthropologist.

The data were analyzed by presenting and later reducing the data based on the research purposes. The next step was analyzing the data from the group or individual statuses in Facebook groups, interviews and focus group discussions with the five ethnicity groups. To ensure the credibility of the data, triangulation with the library sources was conducted. The next steps were analyzing the data and drawing 
a conclusion.

\section{Finding and Discussion}

\section{Topics Discussed in Facebook Groups:} Balinese

KBBS is a Facebook group for a Balinese ethnicity group. KBBS stands for Keluarga Besar Bali di Salatiga. KBBS consists of not only Balinese college students, but also Balinese people who got married and settled in Salatiga as well as many Balinese alumni who are working. The members of KBBS are not always pure Balinese. They can be a mix between Balinese and other ethnicity.

KBBS is a communication forum for Balinese people who study at Satya Wacana Christian University. There are several reasons why they join this group; they are college students who study far from their hometown and they expect to find new friends and family in Salatiga so they do not feel alone in a new place. The members are not force to join the group. In fact, there are Balinese students who do not join KBBS group.

In the interview, Vita, one of the KBBS members who is also a student of communication study department in Faculty of Social and Communication Sciences, SWCU, stated that KBBS is mainly used to provide announcements, such as monthly worship schedule and information about college events.

"Biasanya tentang ibadah, ibadah tiap bulan, atau acara-acara yang menyangkut orang bali yang ada di salatiga atau ada acara di gereja terus kita di minta pimpin ibadah di sana, itu kita di bicarakan di group dan juga acaraacara di kampus IICF, dan undanganundangan acara-acara lainya, rapatrapat untuk kegiatan etnis bali dikampus ya kita bahas di group." (We generally discuss about monthly worship, events involving Balinese in Salatiga or events in churches where we are asked to lead the worship. We discuss about those topics in the group. We also discuss about college events, like IICF and invitations to other events or meetings to talk about Balinese events in the university. So, we discuss them in the group.)

Aside from providing information and announcement, KBBS Facebook group is also used by its members to sell products in order to raise fund for particular event. Furthermore, KBBS is not only used to discuss about the worship schedule, but also to post advice from elders in Bali and job vacancies from alumni. Occasionally, it is used by some alumni to say hello to other members.

So far, KBBS Facebook group is rarely used to discuss topics related to ethnicity, such as information about issues happening in Bali. One of the issues that once were discussed in the group is the reclamation issue in Bali. This issue was not discussed for a long time. KBBS members mainly discuss about other topics, such as the implementation worship or meeting plan together.

Facebook has not yet become the main communication medium for KBBS. KBBS prefers to use other medium which is Blackberry Messenger (BBM) to exchange information and discuss things between members. This statement is mentioned in Vita's statement in the interview on June 29, 2016.

"Masih sangat kurang mbak, kita banyak diskusinya ya pas saling ketemuan, apapun dibahasnya pas dikelompok secara langsung. Ya grup itu kayak sekedar aja kalau kita punya grup, tapi grup itu memang tidak dimanfaatkan maksimal, kita lebih banyak diskusi langsung." (There is not much discussion. We often discuss things when we meet each other. Whatever topic we discuss, we discuss it directly in the group. The group is like a usual group, but it is not used optimally. We prefer to discuss things directly.)

It implies that KBBS Facebook group is 
only used as a medium to provide information such as worship schedule, college activities, meeting schedule and advice as well as to raise fund.

\section{Bataknese}

Bataknese is one of the ethnicities in Indonesia. It is divided into five groups, namely Batak Karo, Batak Toba, Batak Simalungun, Batak Pak-Pak and Batak Mandailing. Based on the observation result in Facebook group Pecinta Budaya Batak, there are several topics that are generally discussed in the group. These topics include information about the pride of being a Bataknese, musical events, marriage of Bataknese and commemoration of Independence Day on August $17^{\text {th }}$.

In its Facebook group cover, there is a slogan stating "Do not feel ashamed as a Bataknese". This slogan implies that the members of this group should be proud of their identity as a Bataknese. This pride is shown in one of the posts in the Facebook group that tells about how the majority of Bataknese are educated to work hard, study diligently to achieve their dreams and be responsible. Using this status, it is expected that many people who read it will understand and remember the characteristics of Bataknese that had been built since they were children.

This group is also used to post articles about Bataknese culture, such as an article about Batak marriage so the members can still maintain and love Bataknese culture. In the Facebook group, there are also many posts about Bataknese local songs. Certainly, with the posts of local songs, the members are reminded of the richness of their culture so those who are far away from Sumatera can relieve their homesickness and maintain their love for their ethnicity.

Issues related to Bataknese are also often posted in this Facebook group as a means of discussion to face them. Thus, when there is a problem, they can discuss it together to prevent the disintegration within Bataknese. For example, when there was an issue about Karo who are not Bataknese, this group posted a relevant topic and opened the discussion by using comments. Based on the positive and negative comments, it is expected that the problem will not cause any disintegration.

\section{Malukunese}

Based on the interview result with Malukunese, the topic that is generally discussed in the group is related to HIPMA (Himpunan Mahasiswa Ambon) activities as mentioned by Thirsa:

"Biasanya sih kalau pemberitahuan kalau ada kegiatan apa gitu seputar HIPMA. Misalnya kayak ada kegiatan apa usaha dana untuk cari dana, kegiatan kita apa gitu pasti diposting. Terus pemberitahuan duka, kabar gembira wisuda, itu biasanya dishare di grup. Trus ada kegiatan yang memerlukan partisipasi temen-temen itu juga pasti di upload di grup itu. Jadi pada tahu semua kan." (Usually there is an announcement about HIPMA activities. For example, fund raising or other activities will be posted. Another example is death announcement and graduation which are usually shared in the group. Then, activities that need participation from other members are also posted in the group. Thus, every member knows about various information)

Aside from interacting with each other in the Facebook group, Malukunese also meet each other face to face. This meeting was recently held in Pattimura Day. The commemoration of Pattimura Day is important for Malukunese because Pattimura is an Indonesian hero from Maluku. Thirsa and Hans, two Malukunese college students acknowledged the importance of Pattimura for Malukunese.

"Kan salah satu pahlawan di Ambon juga ya mba, Maluku. Jadi kayak untuk memperingati perjuangannya gitu. Jadi ditandai dengan adanya Hari Pattimura. Itu biasanya ada obor, itu 
jalan."(Because Pattimura is one of the heroes in Ambon, Maluku. So, Pattimura Day is celebrated to commemorate his struggle. Usually there is a tradition to carry torches.)

For Thirsa, the commemoration of Pattimura Day is to commemorate the struggle of this Malukunese hero. One of the traditions is a parade of people carrying torches.

"Karena kalau di Ambon tuh, apa namanya kan pahlawan dari Maluku kan satu-satunya yang terkenal kan Thomas Matulesi jadi istilahnya kita disebut Pattimura. Jadi kalau di Ambon tuh biasanya setiap kampung atau setiap desa-desa pedalaman tuh mereka buat acara seperti itu mba, bahkan berharihari sampai seminggu dan itu identik dengan sebuah obor. Jadi misalkan satu obor itu dia jalan dari satu desa ke desa yang lain sampai di pusat di kota Ambon."(Because in Ambon, the only famous hero from Maluku is Thomas Matulesi, which we call Pattimura. So, in Ambon, each village usually holds an event like that, sometimes even for several days or a week. This event is associated to torches. So, a torch should be carried from one village to another until the city center in Ambon.)

Similar to Thirsa's opinion, Hans also experienced the same thing as Thirsa related to Pattimura Day. This commemoration does not only last for one day, but several days even a week. One of the traditions is carrying torches from one village to another until they reach the city center in Ambon.

Pattimura Day is also discussed in the Facebook group. Thirsa mentioned that the discussion about Pattimura Day usually includes the history of, activities in and the event time of Pattimura Day in Ambon.

"Iya, biasanya tentang sejarahsejarahnya, terus kegiatan yang berlangsung di daerah misalnya di Ambon gitu, kegiatannya dari jam sekian sampe sekian pasti diposting juga."(Yes, the history of Pattimura, activities in the several regions, such as Ambon and the events time will also be posted.)

\section{Papuanese}

The community for Papuanese in Salatiga is called HIMPPAR (Himpunan Mahasiswa Pelajar Papua Barat). HIMPPAR has gone through several name changes based on the amendment of AD/ART. At first, HIMPPAR was known as PERMIJA (Persatuan Mahasiswa asal Irian Jaya) and later on March 30, 1986, the name was changed into HIPMIJA (Himpunan Pelajar dan Mahasiswa Irian Jaya). Later, the name was changed again into HIMPPAR due to the current development in West Papua as a form of solidarity and acknowledgment of Papuanese rights and identity. This organization is located in Damardjati Street, Salatiga, Central Java. The HIMPPAR Facebook group was established in 2012 as a medium to exchange information, with the HIMPPAR visions and missions as its basis.

Observing the HIMPPAR Facebook group cover, this group has two types of groups: a closed and open group. The closed group can only be accessed by the group members (Papuanese), while the open group can be accessed by other people who want to know about HIMPPAR and Papua. This group shares activities of the organization committees and students as mentioned by Daniel Sihite, a Papuanese college student who is continuing his master study in SWCU in the interview conducted on May 24, 2016:

"Ngomongin hanya berkaitan dengan segala progam kegiatan oleh badan pengurus, seperti expo budaya, kemudian perkuliahan, informasi berkaitan dengan siasat, itu semua tetap tetapi ketika terjadi pergantian ketua pimpinan himpunan."(We only talk about the programs from the committee, such as cultural expo and course, as well as information related to 
the Academic Information System of Satya Wacana Christian University (SIASAT).

This Facebook group is a means of communication for Papuanese college students who study outside Papua; in this case, in Salatiga. Technically, new Papuanese college students in SWCU will be invited by the administrators to join the group, and they usually have to accept the invitation. The purposes of this organization are to: (1) gather college students and students from West Papua who are studying in Salatiga and develop talents and potentials of the members in the group; (2) build and strengthen close relationships between West Papuanese in Salatiga. Therefore, the posts in this group mainly contain information related to courses, college activities, ministry and other important announcements. In the group, each member can support each other through their posts. It shows that each member of HIMPPAR supports each other in their study outside Papua, in Salatiga. Another example is in particular moments, such as Valentine Day, Christmas, Passover or graduation, each member will congratulate other members to strengthen their brotherhood.

Using this HIMPPAR Facebook group, each member can give announcement, such as when they plan to do a meeting or gathering or do other activities. This group also serves as a means of learning from other information. For example, when there is a presidential election in Indonesia, there is a post in this Facebook group that encourages their members to give their voice in the election.

Therefore, it can be seen that the HIMPPAR group is really used optimally by its members to exchange information, build solidarity between their members and maintain their interest in culture by respecting each other.

\section{Kalimantanese}

PAMPAKAT is one of ethnic groups in Salatiga. PAMPAKAT stands for Perhimpunan Alumni Mahasiswa dan Pelajar Kalimantan Tengah. This community is now located in
Salatiga, Central Java. Their Twitter account is @pampakat. Moreover, they also have blog address: http://pampakat2014.blogspot. $\mathrm{com} /$. However, when the researchers wanted to observe their blog, the website could not be found.

One of the activities done by PAMPAKAT is raising fund to help the victims of forest fires in Kalimantan recently. According to Pernando, the leader of PAMPAKAT, several members of PAMPAKAT once went around Salatiga to ask for donation from the people. The collected fund was given to the victims of forest fires in Kalimatan.

\section{The Spread of Nationalism in Facebook Group: Imagination about Ethnicity}

Before talking about the spread of nationalism, the researchers will first explain about the concept of nationalism used in this research. The concept of nationalism used in this research is imagined community proposed by Benedict Anderson. Anderson (in Adisusilo, 2010), defined a nation as "an imagined political community and imagined as both inherently limited and sovereign". According to Anderson, the use of the term "imagined" is important because the majority of the members of this nation have never met each other. However, at the same time, there is an imagination in their mind that they are parts of a particular community because living in an imagination can be defined as living and interacting in a positive way. Therefore, the meaning of nationalism here is further understood as something that is alive and dynamic. This perspective presupposes that nationalism is something that is alive, dynamic and developing which look for new forms along with the development and future demands.

In relation to nationalism, Anderson proposed the concept of imagined community when he saw many countries achieved their independences from colonialists at that time. Similarly, an anthropologist from Satya Wacana Christian University, Dr. Pamerdi Giri Wiloso stated: 


\begin{abstract}
"Pemikiran Imagine Community muncul terkait Anderson mulai melihat merdekanya banyak masyarakat dari penjajahan. Problematik yang dilihat oleh Ben Anderson adalah setelah merdeka dari kolonial lalu masyarakat katakanlah masyarakat mengembangkan diri menjadi sebuah bangsa, menjadi sebuah negara. Nah di dalam membangun bangsa, Ben melihat strategi pembangunan bangsa melalui konsep imagine community."(The idea of imagined community emerged as Anderson started to see the independences of many nations from colonialists. The problem observed by Ben Anderson is, after their independence from colonialists, the community or society calls themselves as a nation and later as a country. Anderson saw a strategy to develop a nation through the concept of imagined community.)
\end{abstract}

Thus, according to Wiloso, Anderson would like to answer the questions of those independent nations. What the latter meant by independent nations are Asia countries, such as Indonesia that achieved its independence from Dutch, Cambodia from England, Vietnam from France, Brunei from England, Malay and Singapore. These countries achieved their independences from colonialists except for Thailand that had never been colonialized.

The next problem faced by the state leader is how these ethnicities, who have called themselves as a nation, then realize that they are parts of a bigger nation, for example Indonesian, Cambodian, Vietnamese or Brunei that consists of many ethnicities. Wiloso stated that a technique to develop a nation and later to maintain it is needed. Anderson observed these problems using the concept of imagined community.

According to what Anderson stated about imagined community, Bataknese as a nation have their principle in marriage; that is to marry within the ethnicity. These values are told from generation to generation. This principle is also stated in the interview with one of the Bataknese. On the other hand, it is also found in the interview that place of birth also influences the realization of oneself's ethnicity. As an instance, if a Bataknese was born and raised outside Sumatera, it will influence his/her understanding about being a Bataknese. For example, a participant named Adolf bears the family name Situmorang and has a Batak Toba father. He stated that he is half Bataknese and half Javanese. His friend, who is also a Bataknese, mentioned that Adolf was born in Kendal, Central Java, and therefore it influences his realization of his ethnicity.

Adolf's experience is similar to Daniel Sihite's experience. Sihite's parentsareBataknese, but Sihite was born and raised in Papua. Sihite stated that he has two ethnicities, Bataknese and Papuanese. Sihite acknowledged himself as a Papuanese as his parents run a business in Papua, and Papua has become a place for his parents to earn a living. However, he is also as a Papuanese because his grandmother had settled in Papua for eighty years due to the transmigration program implemented in Soeharto era at that time. Thus, historical and domicile reasons have made Sihite acknowledged himself as a Papuanese.

"Oh, papah mamah berwirausaha di Papua, nenek dulu tahun 80 sudah merantau di Papua. Jadi dulu di jaman Soeharto sudah dikirim transmigrasi ke Papua, bapak sekolah di sana ketemu sama mamah sesame orang batak dan lahirlah kami." (My father and mother are entrepreneurs in Papua. My grandmother had lived for 80 years in Papua. So, in Soeharto era, she was sent to Papua in a transmigration program. My father went into a school there and met my mother who was also a Bataknese. Then, I was born.)

On the other hand, Sihit is also as a Bataknese because the Bataknese blood flows 
within him. His parents are both Bataknese as well as his grandmother who had lived in Papua for eighty years.

"Yang sangat menggebu di hati ini saat ini memang Papua banget, cuma kalau mau dibilang etnis apa saya mengatakan Batak. Saya Batak Toba, cuma kalau tanya lahir besar pasti di Papua dan tidak bisa menyangkal." (What I acknowledge the most is Papuanese. However, if someone asks me what my ethnicity is, I will say Bataknese. I am Batak Toba. However, if someone asks me where I was born, I will say Papua and won't deny it.)

\section{Techniques to Build and Maintain an Imagined Community}

As previously explained, the imagination of a community needs specific techniques or methods. There are various techniques to build and later maintain an imagined community. According to Wiloso, in Indonesian context, one of the techniques to build and maintain imagined community is by doing flag ceremony on the Independence Day every seventeenth of August.

"Komunitas yang diangan-angankan, yang dibayang-bayangkan walau tidak pernah ketemu toh komunitas itu se-Indonesia seperti Peneliti ya ketemu dengan orang-orang yang dari Kalimantan, Sumatera itu pun nggak pernah ketemu. Maka dengan imagine community membayang-bayangkan yang tidak pernah ketemu tadi juga sebagai bagian dari bangsa besar, Indonesia. Nah untuk merawat imajinasi, menguatkan bayang-bayang sebagi bangsa yang besar dan baik dipakailah segala sarana upacara 17 Agustus, ..... waduh kita membayangkan semua yang ada di nusantara ini bangsa Indonesia melaksanakan upacara tersebut. Dengan lagu-lagu yang perjuangan sampai menitikkan air mata." (The imagined community is imagined even though the members of the community in Indonesia such as from Kalimantan and Sumatera -just like researchers- never meet each other. So, with the concept of imagined community, they can imagine people who they never meet as parts of a bigger nation, Indonesia. To maintain and strengthen the imagination as a big and good nation, we use flag ceremony on the seventeenth of August. ...... We imagine everyone in Indonesia does the ceremony accompanied by patriotic songs until we shed tears)

According to Wiloso, in its development, mass media at that time also helped to build an imagined community. The existing mass media also strengthened the imagination of a community.

"Nah Ben melihat juga surat kabar, setelah itu dicetak itu nambah untuk menguatkan angan-angan, bayangbayang, sekian banyak orang sebagai sebuah bangsa. Jadi ketika kita membaca sebuah surat kabar, kita diperkuat bayangan kita oh orang papua yang kekurangan air, ..... bangsa, menjadi satu bangsa, mari kita tolong. Komunitas yang sesungguhnya terbayang-bayang saja, angan-angan saja, makanya bodoh kalau aku hidup di angan-angan saja. Walau kita nggak pernah ketemu, walau kita nggak pernah berjua, nggak pernah apa, tapi seolah-olah kita satu bangsa dengan perantaraan media-media itu, 17 agustus apa lagi lagu-lagu kebangsaan bahkan majunya teknologi cetak, koran, televisi, radio lebih lagi menguatkan angan-angan kita semua sebagai satu bangsa."(Well, Anderson also observed newspaper. After that, the newspaper is printed to strengthen the imagination of so many people as a nation. So, when we read a newspaper, our imagination of community is strengthened. "Papuanese 
lacks of water...... We are one nation, let's help them!" The real community is only imagined in our mind. So, it is stupid if I only live in the imagination world. Even though we never meet, never see each other, never do anything together, but it is as if we are parts of a nation with the existences of social media, seventeenth of August, patriotic songs, even the advancement of printed technology, newspaper, television and radio. Those media strengthen our imagination as a nation.)

This research also suggests several methods to build and maintain the imagination of a community. For example, Malukunese have their own ways in building and maintaining the imagination as a bigger nation, Indonesia. For Malukunese, one of the ways to maintain an imagined community as an Indonesian is by commemorating Pattimura Day. According to Hans, Pattimura Days is commemorated from generation to generation and by all Malukunese in all regions in Indonesia.

"Setiap orang Maluku yang ada di luar Ambon, yang di Jawa gitu kan buat komunitas dan mereka melakukan hal yang sama tapi nggak sampe yang sesakral di Ambon sih, paling selintas kayak kita nyanyiin lagu-lagu Ambon atau ada orang-orang tua yang udah lama gitu kan yang istilahya jadi tetua, kita undang untuk kasih arahan untuk kita."(Every Malukunese outside Ambon, for example in Java who create their own community, do the same even though it is not as sacred as in Ambon. They just sing Ambonese songs or some older people, which we call elders, are invited to give advice to us)

Hans stated that he had been told from his childhood about the meaning of igniting torches and parade in several locations.
"Iya pasti tahu, karena dari SD (Sekolah Dasar)pun, dari kita kecil pun udah seperti itu mbak, jadi udah lihat ooh ini hari Pattimura terus diajarin itu apa, siapa, begitu tau. Kayaknya pas ke sini kita rayain hari Pattimura itu bukan cuma satu agenda yang betul-betul tapi udah biasa gitu kan dari dulu-dulu dari angkatan sebelumnya udah harus seperti itu. Kita tinggal lanjutin, lanjutin, lanjutin, lanjutin aja. Begitu sih."(Yes, we certainly know because in Elementary school, even in our childhood, we had been told about that. So we know that today is Pattimura Day, who Pattimura is, etc. When we went here, commemorating Pattimura Day is not only a real agenda, but also a tradition from the previous generations. We only need to continue it again and again. It's just like that.)

In Ambon, the commemoration of Pattimura Day does not only last for one day, but several days even one week.

"Karena kalau di Ambon tuh, apa namanya kan pahlawan dari Maluku kan satu-satunya yang terkenal kan Thomas Matulesi jadi istilahnya kita disebut Pattimura. Jadi kalau di Ambon tuh biasanya setiap kampung atau setiap desa-desa pedalaman tuh mereka buat acara seperti itu mba, bahkan berharihari sampai seminggu dan itu identik dengan sebuah obor. Jadi misalkan satu obor itu dia jalan dari satu desa ke desa yang lain sampai di pusat di kota Ambon."(Because in Ambon, the only famous hero from Maluku is Thomas Matulesi, which we call Pattimura. So, in Ambon, each village usually holds an event like that, sometimes even for several days or a week. This event is associated to torches. So, a torch should be carried from one village to another until the city 
center in Ambon.)

The spread of awareness as an Indonesian by Malukunese is perfomed using social media. Hans and Thirsa stated that they know the events of Pattimura Day in Ambon through the posts in HIPMA group. Thirsa is also aware that nowadays, technology has been developing significantly with the presence of internet, especially Facebook. The advancement of technology really helps the distribution of information. Thirsa chose to use Facebook because not only cheaper compared to short message service, it is also one of social media that is accessed by many people every day. The distribution of information about Pattimura Day is also done using Facebook.

A little bit different to KBBS group, Balinese use two media to create and maintain nationalism within their community. Facebook is still one of the options in distributing information about Balinese activities and events. The other medium used by Balinese is Blackbery Messenger (BBM). Vita preferred to use BBM as it is more personal. The members in the BBM group are limited to 30 people. Information shared in the Facebook and BBM groups are mainly about the religious events for Balinese.

In relation to nationalism and mass media, Sri Hastjarjo, Ph.D., academics who specializes on mass communication filed in Universitas Sebelas Maret, Surakarta, agreed with Anderson's opinion that stated that mass media play a key role in creating an imagined community.

"Gagasannya Anderson adalah bahwa gagasan sebuah bangsa itu sebenarnya adalah sebuah komunitas yang itu hanya dibayangkan di level konsep, dan peran utama. Saya setuju dengan Benedict Anderson bahwa peran utama yang membentuk gagasan adalah media massa. Karena gagasan itu kan biasanya dibentuk oleh elit. Elit biasanya, kalau konsep Indonesia kan para elit yang memiliki gagasan berbangsa." (Anderson's idea is that the idea of a nation is in fact a community imagined in the concept level and main role. I agree with Benedict Anderson that mass media is the key role in forming an idea because an idea is usually formed by elites. In the concept of Indonesia, elites have the idea about a nation)

Talking about mass media, Hastjarjo stated that one of the roles of mass media is to inspire the idea of imagined community.

"Saya pikir itu peran utama bahwa media itu menjadi kendaraan yang difungsikan oleh gagasan tentang bangsa. Gagasan tentang kita ini sebagai satu komunitas, sekalipun pada plakatnya kita tidak pernah ketemu, tidak pernah interaksi. Tetapi disatukan oleh satu nasib, satu badan dan satu tujuan yang ingin dicapai." (I think the main role of media is as a means to create a imagination as a nation; the idea of us being a part of one community even though in fact we never meet or interact with each other. However, we are united with one fate, one body and one reason that we want to achieve)

Therefore, the new concept resulted from this research is about the roles of mass media in society. Previously, it is found that mass media function as a means of entertainment, education, etc. Through this research, there is an additional role of mass media, which is to raise nationalism.

In relation to social media used in this research to observe the spread of nationalism, Hastjarjo stated that it has a weakness. The weakness is that social media do not have centralized information flows.

"Salah satu persoalan dari media sosial dan media online itu adalah kemungkinan tidakadalagialiranpesanyangterpusat.... 
setiap orang punya agendanya sendirisendiri, punya gagasan dan imajinasi sendiri tentang bangsa seperti apa dan semua orang punya saluran untuk mengatakannya."(One of the problems of social media and online media is that the centralized message flows may not exist anymore... Everyone has their own agenda, idea and imagination about the nation, and everyone has their own ways to state it.)

Then, the idea of criticism towards Anderson's theory emerged. Can nationalism be defined together with the presence of social media which are not centralized nowadays? Hastjarjo stated his criticism towards Anderson's concept:

"Itu dinamika yang kemudian muncul, mungkin tidak apakah itu akan bisa dipakai untuk memutuskan sebuah identitas gagasannya Bendecit Anderson di awal?.(It is the dynamic that later emerges. Is it possible to use the initial concept proposed by Benedict Anderson to determine an identity?)

\section{Conclusion}

The conclusion of this research is every ethnicity has their own imagination of community. This imagination may include imagination of their own community and imagination of a bigger community. Papuanese in their Facebook group provide information about cultural events in Papua. It creates an imagination as a Papuanese who is proud of their culture. In this research, Sihite is proud to be a Papuanese because of his historical and domicile reasons. On the other hand, Malukunese Facebook group shares information about daily activities. Activities that are generally posted are related to cultural performances. Each year, Malukunese commemorates Pattimura Day. The commemoration of Pattimura Day is posted in their group. Posting the commemoration of
Pattimura Day shows that Malukunese have their own pride to be a part of their ethnicity and that they are parts of Indonesia because Pattimura is considered as a national hero.

Different from Balinese who have a Facebook group and Blackberry Messenger group, the group generally shares information about common activities, religious activities and information from their their adoptive mother in Salatiga. Information on the Facebook group is more general, while information shared in the BBM group is more personal. The members in BBM group are also limited compared to the Facebook group.

Bataknese also have a Facebook group. Information posted in the Facebook group is also general. The information generally is related to activities done by Bataknese. For Bataknese, the importance of marriage within the same ethnicity is always toldd from generation to generation. This information is also posted in the Bataknese's Facebook group. In an interview with one of the Bataknese who was born and raised in Central Java, he acknowledged himself as a Bataknese and Javanese. Furthermore, place of birth influences their identities.

Kalimantanese have a group account named PAMPAKAT. In an interview with the head of PAMPAKAT, it is found that the sense of belonging as Kalimantanese is shown through their effort in raising funds from Salatiga people. The collected fund is used to help their people who suffer from forest fires in Kalimantan.

In the analysis level, it is found that for Malukunese, they maintain this nation by commemorating Pattimura Day annually. The media used to provide information about this event are social media. One of the social media used is Facebook. Another thing done by all ethnicities to create and maintain the imagination as an Indonesian is by holding and joining Indonesia International Cultural Festival (IICF). IICF is considered by all ethnicities as an opportunity to introduce their ethnicities to society and show that they are parts of a bigger community, Indonesian. One of the media used to 
share the imagination of this nation is Facebook.

In the process of data triangulation, the researchers found several things that can be used to help the analysis of this research. Those things include the roles of mass media in creating an imagined community and social media flows which are not centralized, thus complicates the imagination of Indonesian as a community. However, the state leader still has to constantly build an imagination as an Indonesian, especially using social media.

\section{References}

Anderson, Benedict. (2008). I $m$ a g $i n$ e d Communities : Komunitas-Komunitas Terbayang. Yogyakarta: Penerbit Insist. Adisusilo, Sutarjo, J.R. (2010). Nasionalisme, Demokrasi, dan Civil Society. diakses dari https://www.usd.ac.id/lembaga/ lppm/f113/Jurnal\%20Historia\%20 $\mathrm{Vitae} / \mathrm{vo} 123$ no 2 oktober $2009 /$ $\mathrm{N}$ A S I O N A L I S M E \% 20 s u t a r jo\% 20 ad is us i 1 o.pdf Adzkia, Aghnia \& Sandy Indra. (2015). Kriteria Situs Islam Radikal Versi BNPT. diakses (http://www.cnnindonesia.com/ teknologi/20150401093434-185-43429/ kriteria-situs-islam-radikal-versi-bnpt/).

Atriana, Rina. (2015). Kominfo Blokir 22 Situs yang Dianggap Radikal, Polisi: Itu Memang Diperlukan. diakses dari (http://news.detik.com/read/2015/10/).

Denis McQuail. (2011). Teori Komunikasi Massa Edisi 6. Jakarta: Penerbit Salemba Humanika.

Nicholas W. Jankowski. (2006). Creating Community with Media. Dalam Leah A. Liverouw dan Sonia Livingstone (Ed.). The Handbook of New Media. London: Sage Publications Ltd. No name. (2015). Facebook Closes in on 1 Billion Mobile Users. diakses dari http:// www.emarketer.com/Article/FacebookCloses-on-1-Billion-Mobile-Users-Wo rldwide/1011881/1? ecid=PR1002).

Rice R.E. (1984). The New Media:
Communication, Research and Technology. California: Sage Publication . Silaban, Winner. (2012). Pemikiran Soekarno Tentang Nasionalisme. Jurnal Dinamika Politik Volume, Nomer 3 bulan Desember 2012. ISSN: 2302-1470. 